(C) 1984. The Genetical Society of Great Britain

\title{
PERICLINAL CHIMAERISM IN PETUNIA DEMONSTRATED BY REGENERATION OF PLANTS FROM THE MUTATED EPIDERMAL LAYER
}

\author{
R. J. BINO, F. BIANCHI AND H. J. W. WIJSMAN \\ Institute of Genetics, University of Amsterdam, Kruislaan 318, 1098 SM Amsterdam.
}

Received 12.vii.83

\section{SUMMARY}

Using flower colour markers that express themselves only in the epidermis, in a stable periclinal chimaera of Petunia it was demonstrated that regenerants from callus grown from pedicels and leaves have the genotype of the epidermal cell layer. When a plant carrying an unstable allele of the gene An1 is tested in this way, occasional branches with a mutant flower colour type appear to have the mutant genotype only in the epidermis.

\section{INTRODUCTION}

Bianchi et al. (1978) have described genetic instability of the An1 locus in Petunia, manifesting itself either as somatic variegation of flower colour, or in mutant progeny. An 1 is a basic factor for anthocyanin synthesis. In the cv. Roter Vogel genetic background as described by Bianchi et al., An 1 action leads to red colour, while the spontaneous mutant allele an $1 *$ induces the development of variegated flowers, white with red spots. However, in certain cases (Doodeman and Bianchi, 1983) reversion is not only to full colour, but also to pale colours of different intensity levels. Reversion to stable white may also occur. When reversion of $a n 1^{*}$ occurs in the primordial stage of the flower, it can be late (small coloured spots), or early (large spots). Mutations in the epidermal layer of the shoot apex may lead to the occurrence of whole coloured flowers or whole branches with coloured flowers. However, anthocyanin synthesis takes place only in the epidermis, and the genotype of the epidermis determines development of pigment. Therefore, a full-coloured flower normally has variegated progeny, the gametes being produced not by the epidermal, but by the subepidermal cell layer. Only in the very infrequent case of a simultaneous reversion in both the epidermal and the subepidermal cell layer (Bianchi and Walet-Foederer, 1974), will such a coloured flower have coloured progeny.

\section{MATERIAL AND METHODS}

\section{(i) Plant material}

The genes $A n 1, A n 2$, and $R t$ have been described by Wiering (1974). In short, $A n$ is involved in colour, while an means white; $R t$ is correlated with rhamnosylation of 3-glucoside anthocyanin; in the background used $R t$ means magenta, $r t$ means red flower colour. The plant with the $R t$ mutation was derived from repeated backcrossing of the original trisomic VI to inbred line A4, and is heterozygous $R \operatorname{tAn} 2 / \operatorname{ran} 2$. 
Variegated-flowering plants were ultimately derived from plant PX5158 L-1 (genotype an $1 *$ an 1 ). The unstable an $1 *$ mutation (Bianchi et al., 1978) is in a peculiar "state" in the terminology of McClintock (1967) and has a phenotype of red or pale red spots and sectors on a white background. In plants of the homozygous type, flowers have red spots, pink spots with smaller red or dark pink spots in the pink, and very occasionally a plain pink spot $\left(\right.$ an $1^{*}$ an $\left.1^{*}\right)$.

\section{(ii) Tissue culture}

Regeneration of pedicels was carried out according to Pelletier and Delise (1969) with the following modifications. As the basis for the medium Flow's mixture 26-100 (macro-elements, micro-elements, vitamins) was used. The flower was cut off just under the ovule. Callus develops all round the pedicel, but 80 per cent of the regeneration was from the callus formed at the apical end. Optimal concentrations of hormones for regeneration were $0.5 \mathrm{mg} / l$ naphthalene acetic acid (NAA) and $0.5 \mathrm{mg} / l$ 6-benzyle aminopurine (BA) for plants with Roter Vogel genetic background; however, for the $R t$ mutants the optima were $1 \mathrm{mg} / l \mathrm{NAA}$ and $0.25 \mathrm{mg} / l$ BA.

Regeneration of leaf tissue was carried out on the same medium with small squares of leaf, but here the optima for regeneration were $0.25 \mathrm{mg} / l$ NAA and $1 \mathrm{mg} / l \mathrm{BA}$. Callus formed on all sides of the squares.

\section{Results}

\section{(i) Regeneration from epidermal cells}

The technique for regeneration of Petunia plants from callus derived from somatic cells as developed by Pelletier and Delise (1969) normally gives rise to plantlets originating from epidermal cells (D. Maizonnier and A. Cornu, personal communication). We have tested the hypothesis by taking a stable magenta-flowering plant (genotype $R t r t$ ) with a red-flowering

\section{TABLE 1}

Flower colour of regenerants obtained from pedicels Flower colour of branch number of regenerants flower colour of regenerants

(a) Red-flowering branch on magenta-flowering plant

\begin{tabular}{ccc}
\hline & & 48 red \\
red & 49 & 1 white \\
\hline
\end{tabular}

(b) Variegated plants (heterozygous an $1^{*}$ an 1 ) having occasional branches with red, unspotted

\begin{tabular}{|c|c|c|}
\hline \multicolumn{3}{|c|}{ pale, or unspotted white flower } \\
\hline red & 16 & 16 red \\
\hline pale & 6 & 6 pale \\
\hline white & 24 & $\begin{array}{l}20 \text { white } \\
4 \text { variegated }\left(\text { an } 1^{*} \text { an } 1\right)\end{array}$ \\
\hline variegated (heterozygous an $1^{*}$ an 1 ) & 36 & $\begin{array}{l}35 \text { variegated }\left(\text { an } 1^{*} \text { an } 1\right) \\
1 \text { white }\end{array}$ \\
\hline variegated (homozygous an $1^{*}$ an $1^{*}$ ) & 9 & 9 variegated (an $1^{*}$ an $\left.1^{*}\right)$ \\
\hline
\end{tabular}

Seven plants were used, all variegated with one or more aberrant branches. Pale-flowering plants can have different colour intensity, but the colour of the regenerants consistently was of the same shade as that of the parental branch 
chimaeric branch ( $r$ trt in the flower pigment-forming epidermal layer). An F2 obtained after self-pollination of flowers from the aberrant branch, however, still segregated for magenta versus white flower colour (data not shown). We regenerated callus derived from pedicels as well as from leaves from the red branch, and in $\mathbf{4 8}$ from 49 cases, the regenerated plant had the red (rtrt) colour (table 1(a)). In the remaining case the regenerant was white. Because the original parent plant was heterozygous for the anthocyanin producing factor $A n 2$, the aberrant regenerant (an2an2) can be interpreted as the result of a mutational event $(A n 2 \rightarrow a n 2)$. Progeny from several red regenerant plants only segregated for red versus white flower colour, in a 3:1 ratio (data not shown); no magenta flowers have been found among 233 progeny plants.

In the variegated-flowering plants used (white with full-coloured and pink spots), somatic mutation may give rise to branches with the flowers either red, different shades of paler colour (pink), or plain white. Pedicels of these aberrant branches were used to form callus. Regenerated plants had the same colour as the branch from which they descended (table 1(b)), with very few exceptions (see Discussion).

(ii) Progeny from chimaeral flowers compared with epidermal regenerants of the same colour

Flowers from aberrant branches of variegated plants were self-pollinated. Because the parental plants were heterozygous, segregation of variegated and white progeny occurs. In addition, the genotype of part of the

TABLE 2

Flower colour analysis in progeny obtained from self-pollination of three different plants and regenerants derived from these

\begin{tabular}{|c|c|c|c|c|c|}
\hline \multirow{2}{*}{$\begin{array}{l}\text { Genetic data on parental plant } \\
\text { and flowers } \\
\text { Progeny from: }\end{array}$} & \multirow{2}{*}{$\begin{array}{l}\text { Genotype of } \\
\text { sporogenic } \\
\text { layer }\end{array}$} & \multicolumn{4}{|c|}{ Segregation of colour types } \\
\hline & & variegated & white pink & red & Total \\
\hline
\end{tabular}

(a) Parent plant: E5136B-500. Phenotype: variegated (heterozygous) with a white-flowering branch

\begin{tabular}{|c|c|c|c|c|c|c|}
\hline $\begin{array}{l}\text { Parent plant, } \\
\text { variegated (normal) flower }\end{array}$ & $\operatorname{an} 1 * \operatorname{an} 1$ & 93 & 54 & 2 & 7 & 156 \\
\hline $\begin{array}{l}\text { Regenerants: } \\
\text { normal flower from normal } \\
\text { branch }\end{array}$ & $a n 1^{*}$ an 1 & 413 & 152 & 2 & 21 & 588 \\
\hline $\begin{array}{l}\text { white flower from white- } \\
\text { flowering branch }\end{array}$ & an 1 an 1 & 0 & 250 & 0 & 0 & 250 \\
\hline
\end{tabular}

(b) Parent plant: C5363-76. Phenotype: variegated (heterozygous) with a red-flowering branch

\begin{tabular}{|c|c|c|c|c|c|c|}
\hline $\begin{array}{l}\text { Parent plant, } \\
\text { red flower }\end{array}$ & $a n 1^{*} a n 1$ & 116 & 52 & 3 & 8 & 179 \\
\hline $\begin{array}{l}\text { Regenerant: } \\
\text { red flower from red-flowering } \\
\text { branch }\end{array}$ & An 1 an 1 & 0 & 38 & 0 & 138 & 177 \\
\hline
\end{tabular}


plants results from mutation in the sporogenic tissue, which gives rise to red, unspotted pink, or unspotted white-flowering plants. The different progenies of the self-pollinations do not deviate from those of the original variegated plant, PX5158 L-1 (table 2).

However, if from callus derived from pedicels of branches with unspotted coloured flowers plants were regenerated, the latter segregate after selfpollination in a 3:1 ratio for coloured: white; no variegated plants occurred (table 2(b)).

From the data, we can conclude that the regenerants from epidermal cells are no longer chimaeric, but form gametes as expected of heterozygous plants with unvariegated flowers. From the ratios obtained, it follows that the plants were diploid (unpublished and table 2). All regenerants had a normal habit, no evidence for the occurrence of aneuploids or polyploids was found.

\section{Discussion}

Callus grown from leaf or pedicel tissue is apparently of epidermal origin in at least a big majority of the cases. Bianchi and Walet-Foederer (1974) have already stressed how unlikely simultaneous mutation in the epidermal layer and in the lower layers would be. With the non-reverting chimaera resulting from a stable somatic mutation from magenta to red $(R t \rightarrow r t)$ the case is straightforward. With the unstable an $1^{*}$ mutant the same phenomenon can be demonstrated when a white branch on a variegated plant is taken; only white-flowering regenerants are found (table 2(a)).

Regenerated plants have the colour of the branch they are derived from; when these differently flowering branches were from one plant, the chimaeric composition of the epidermal layer is obvious. Bianchi (unpublished observations) has self-pollinated scores of mutant-coloured branches, finding that the progeny is consistently derived from the unmutated underlying layer.

As to the progeny of the regenerated plants, reversion of the instable an $1^{*}$ allele to full colour ( $\left.A n 1\right)$ essentially eliminates the possibility of finding variegated plants among the descendants since heterozygous parents were used, the other allele being a fully recessive stable an 1 mutation.

In table 2(b) two cases require comments. Amongst regenerants of a variegated-flowering branch $1 / 36$ was white. The aberration can be ascribed to a mutation of the type $A n 1^{*} \rightarrow$ an 1 , which is of frequent occurrence (about 1 per cent, Doodeman and Bianchi, 1983). Amongst 24 plants derived from a white branch, 4 had variegated flowers. Several explanations are possible. Back-mutation from white to variegated has up to now not been observed. More likely is that in the white branch a sector was still present of unmutated cells of variegated genotype. The possibility that subepidermal layers contributed to the embryo at the pedicel surface cannot be excluded. Because a contribution of subepidermal layers potentially could only be shown in the cases of table 1 (a) as well as in the pale and white plants of table 1(b), the maximum number of cases with such a hypothetical subepidermal contribution would be 4 in $79(49+6+24)$.

Interestingly, the description of regeneration in Petunia by Handro et al., (1973) shows regeneration of shoots originating in the cambial layer (of the stem), with callus actively breaking out through the epidermis. 
Pedicels, however, seem to be destined for growth in longitudinal direction, while leaves lack a cambium layer. Initiation of embryoids from (aberrant, highly cytoplasmic) epidermis cells has been described for Ranunculus sceleratus by Thomas et al., (1972). Another case has been mentioned by Bigot (1976).

Summarising, the presence in plants carrying the unstable an $1^{*}$ allele of the postulated genotypes in the epidermis of mutant branches has been proved.

\section{REFERENCES}

BIANCHI, F., CORNELISSEN, P. T. J., GERATS, A. G. M. AND HOGERVORST, J. M. W. 1978 Regulation of gene action in Petunia hybrida: Unstable alleles of a gene for flower colour. Theor. Appl. Genet., 53, 157-167.

BIANCHI, F. AND WALET-FOEDERER, H. G. 1974. An investigation into the anatomy of the shoot apex of Petunia hybrida in connection with the results of transformation experiments. Acta Bot. Neerl., 23, 1-6.

BIGOT, C. 1976. Bourgeonnement in vitro à partir d'épiderme séparé de feuille de Bryophyllum daigremontianum (Crassulacés). Can. J. Bot., 54, 852-867.

DOODEMAN, M. AND BIANCHI, F. 1983. Genetical analysis of instability of Petunia hybrida. Part 1. A highly unstable allele induced by a transposable element inserted at the an 1 locus. Part 2. Chimaeras as the result of mutations of unstable alleles of gene $A n 1$ for flower colour. Theor. Appl. Genet., 67, 345-366.

HANDRO, W.. RAO, P. S. AND HARADA, H. 1973. A histological study of the development of buds, roots, and embryos in organ cultures of Petunia inflata R. Fries. Ann. Bot., 37, 817-821.

MCCLINTOCK, B. 1967. Genetic systems regulating expression during development. Developmental Biology Supplement 1, 84-112. Control mechanisms in developmental processes; ed. M. Locke, Acad. Press, New York \& London.

PELletier, G. AND DELISE, B. 1969. Sur la faculté de régéneration de plantes entières par culture in vitro du pédoncule floral de Petunia pendula. Ann. Amélior. Plantes, 19, 353-355.

THOMAS, E., KONAR, R. N. AND STREET, H. E. 1972. The fine structure of the embryogenic callus of Ranunculus sceleratus. L. Cell Sci., 11, 92-109. 